\title{
NA CONTRAMÃO PARA O RUMO CERTO
}

Neste editorial gostaria de convidar todos os partícipes da Revista Psicologia em Estudo - autores, consultores, integrantes da equipe e do conselho editorial e, em especial, os leitores - a empreenderem uma reflexão sobre os dilemas éticos e científicos de nossa época.

Vivenciamos, nestas últimas décadas, o que alguns chamam de capitalismo tardio, outros de pósmodernidade. Deixando-se de lado, neste momento, as diferentes terminologias, o que se evidencia é o acirramento das contradições de toda ordem geradas pela atual crise do capitalismo. Embora tenha origem em aspectos econômicos intrínsecos à própria ordem do capital, esta crise é de nosso interesse. Independentemente das abordagens teóricas que adotemos ou das esferas de atuação que assumamos, enquanto pesquisadores e profissionais do âmbito da Psicologia sabemos que ela gera contradições que determinam e contaminam as relações, ou mesmo nela se expressam, impactando a subjetividade dos indivíduos.

$\mathrm{Na}$ nova roupagem assumida pela velha ordem capitalista acaba prevalecendo a política do casuísmo, das trocas de favores e benefícios pessoais, do uso do bem público como privado, o que pode ser identificado, por exemplo, nos conteúdos que veicula a mídia nacional e internacional. Como dizia o velho Marx, em uma de suas máximas, "é a guerra de todos contra todos" que a cada ciclo de crise se reaviva e se intensifica, comparando-se a uma selva na qual a ética definha e perece.

Ao participar recentemente de um curso de editoração científica, disposta a aprender o ofício de gerenciar um periódico científico para poder, juntamente com a equipe editorial, zelar pela qualidade das produções e conduzir com seriedade a tarefa à qual juntos nos propusemos, surpreendi-me com a grande ênfase dada às atitudes antiéticas e aos problemas referentes à má conduta científica, o que gerou debates, discussões e preocupações que envolveram todos os participantes. Grande parte dos palestrantes apontou o crescente número de casos de má conduta na seara científica como decorrente das altas exigências postas aos pesquisadores com referência à produtividade.

Instaura-se, ou melhor, revela-se de maneira contundente, no meio científico, a expressão daquilo que há séculos já se vem mostrando nas relações de trabalho externas à academia. Com isso, indago quanto o acirramento da lógica competitiva entre cientistas e pesquisadores - nacionais e internacionais - conduzida por avaliações mais quantitativas do que qualitativas pode contribuir ou ser, de algum modo, saudável para a Ciência. Quando a ênfase das avaliações recai sobre a primeira natureza citada e o motor do processo é alimentado por fazer mais em menos tempo, referendam-se os ensinos maquiavélicos de que "os fins justificam os meios".

Não é desconhecido que o operário há muito tempo foi transformado em mais um número, ou em uma peça da máquina, não mais se percebendo onde inicia a máquina e onde termina o homem nos setores operacionais. Nestes últimos anos vemos a produção científica caminhar em um rumo semelhante. Precisamos parar para refletir, mesmo nesta sociedade que em nada nos favorece em relação a isto, e nos perguntar o que tem feito esta ciência aligeirada para tornar a vida humana melhor e realmente gerar para a população melhores condições educacionais, de saúde, de trabalho e de alimentação. O nosso foco não pode e não deve ser o que nos está sendo exigido, isto é, a quantidade - de artigos, de pesquisas, de citações, ou o índice $H$ de cada pesquisador - mas o impacto da nossa produção nas diferentes esferas da vida humana.

É preciso que identifiquemos e enfrentemos essa lógica perversa que se impõe aos partícipes deste processo de gerar ciência, pois esta não deveria transformar-se em um bem particular, em um mérito ou em meio de alcançar benefícios; antes, ela deve voltar-se para o coletivo, para a sociedade, movendo a engrenagem na direção contrária.

Essa situação criticada me leva a recorrer ao tão conhecido operário de Charles Chaplim, do filme "Tempos Modernos", e a questionar: estamos sendo conscientemente conduzidos à estereotipia e à reprodução, despindonos da capacidade de pensar e de nos posicionar a esse respeito? Como todo processo de desumanização, tal situação não se faz sem os dilemas éticos postos pela mecanização e coisificação do humano. Em relações assim 
constituídas, repletas de contradições, em que imperam números e abstrações, e não pessoas, tem-se a degradação. Sob a lógica criticada, na prática social não se roubam mais somente objetos e propriedades outrora identificados por terras e outros bens materiais, mas agora se roubam também idéias e produtos intelectuais. Isso permite que se forjem dados, status, e quanto mais se criam mecanismos de controle e de medição, mais se reforçam os mecanismos transgressores movidos pela competição - expressão das relações sociais de produção.

Vejo com preocupação os caminhos que estamos tomando e compartilho a imperiosa necessidade de problematização desses caminhos no meio científico e acadêmico, principalmente na área de Ciências Humanas. Enveredar por esta lógica individualista e produtivista de valorização da produção científica em termos puramente quantitativos pode significar o abandono das finalidades últimas das ciências em geral e das humanas em particular: contribuir para a humanização da natureza e do homem.

Espero que este editorial gere novas reflexões e a partir dele convido os leitores a adentrarem neste número em busca de respostas aos problemas existentes, pois cada artigo, a partir de sua abordagem teórica ou mesmo do recorte realizado no estudo proposto, oferece contribuições importantes para a Psicologia que almejamos.

Boas reflexões!!

$\operatorname{Prof}^{a}{ }^{D}{ }^{a}$ Silvana Tuleski Editora 